\title{
MENADŽERSKI ASPEKTI MEĐUZAVISNOSTI ZAŠTITE ŽIVOTNE SREDINE I BUDŽETA
}

Finansiranje zaštite životne sredine predstavlja jedan od osnovnih zadataka svake savremene države. Fokusirajući se na finansijsku instituciju kakva je budžet možemo predstaviti stepen potreba $\mathrm{i}$ mogućnosti zadovoljenja osnovnih potreba u vezi uspostavljanja i funkcionisanja sistema zaštite životne sredine.

Koristeći statističke metode predstavićemo uzročno posledične odnose između elemenata sistema zaštite životne sredine i njihovog finansijskog uporišta u ekonomskoj moći države u savremenim uslovima na promeru Republike Srbije.

Ključne reči: budžet, zaštita životne sredine, finansiranje.

\section{UVOD}

Finansiranje zaštite životne sredine predstavlja jedno od najvažnih pitanja svake savremene države. Finansijska institucija kao što je budžet predstavlja veliki oslonac zadovoljenja potreba za novcem u vezi sa tim.

S obzirom da se zaštita životne sredine finansira pored nekoliko izvora finansiranja, kao što su finansiranje iz sektora privrede, prihoda od naknada i izvora međunarodnih donacija, u najvećoj meri iz budžeta Republike Srbije, u radu ćemo obraditi upravo finansiranje zaštite životne sredine iz budžeta Republike Srbije.

Važnu ulogu u zaštiti životne sredine ima Agencija za zaštitu životne sredine koja svojim statističkim podacima u velikoj meri utiče na odgovorno ponašanje pravnih i fizičkih lica kao velikih zagađivača životne sredine. To za posledicu ima domaćinski odnos prema zaštiti životne sredine što se pozitivno odražava na društvo u celini. Zbog toga je neophodna pozitivna korelacija između izdvajanja finansijske institucije kao što je budžet i sektora privrede koji uzajamnim delovanjem mogu u velikoj meri da doprinesu zaštiti životne sredine. Takođe, neophodno je da se glavni teret finansiranja zaštite životne sredine premesti sa budžeta Republike na zagađivače i namenske fondove za zaštitu životne sredine.

S obzirom da Republika Srbija ima projektovan cilj u vezi sa priključenjem Evropskoj Uniji (EU) neophodno je usaglašavanje, kako načina finansiranja tako i modela zaštite životne sredine uopšte. Zbog te činjenice, ne možemo a da ne dotaknemo budžet zamalja EU kao i udeo u njihovom BDP (domaći bruto proizvod) za finansiranje zaštite životne sredine.

\section{METODE}

U radu koristimo metodu korelacije kako bi utvrdili odnos stanja i strukture rashoda finansiranja iz budžeta i pojedinačnih činilaca zaštite živitne sredine u Republici Srbiji. U cilju sagledavanja ekonomskih činilaca i načina finansiranja budžetskog dela zaštite životne sredine sa jedne strane i elemenata zagađivanja zaštite životne sredine koristićemo različite analitičke pokazatelje. Jedna od osnovnih varijabli je BDP i budžet Republike Srbije biće polazna veličina razmatrana u ovom istraživanju. Pored toga koristiće se i odnosi između budžetskih aproprijacija koje predstavljaju udele na rashodnoj strani budžeta (Štiglic, 2008) opredeljene za namene finansiranja izdataka zaštite životne sredine što je ujedno pokazatelj udela rashoda u ukupnoj državnoj potrošnji kao sastavnom delu GDP-a.

Kao mera stanja zaštite životne sredine koriste se pokazatelji količine otpadnih voda iz industrije u hiljadama kubika, količina prečišćene otpadne vode u hiljadama kubika i godišnjoj količini otpada u Srbiji.(Radičić i Raičević, 2111) Ovi pokazatelji upućuju na stepen ulaganja industrije u zaštitu životne sredine u odnosu na izdvajanje iz budžeta za zaštitu životne sredine.

U radu koriste se podacima Narodne banke Republike Srbije, Agencije za zaštitu životne sredine, Zavoda za statistiku Republike Srbije, period od 2010. do 2014. godine.

\footnotetext{
${ }^{5}$ Visoka škola za menadžment i ekonomiju, Kargujevac, simeunovict@gmail.com 
Za potrebe istraživanja koristili smo model $G D P=C+G+l+X-M$, rashodnog metoda utvrđivanja BDP u kome $C$ označava ličnu potrošnju, $G$ javnu potrošnju, I investicije, $X$ izvoz, a $M$ uvoz(Burda i Viploš, 2012).

$\mathrm{U}$ toku istraživanja primenili smo model korelacije Pirsonovog koeficijenta $r x y=C x y / S D x \cdot S D y$, gde Cxy označava kovarijansu, a SDx · SDy, proizvod standardnih devijacija h i y.(Burda i Viploš, 2012)

Kako bi izvršili procenu vrednosti u narednom periodu zavisno od ekonomskih kretanja koristili smo metodu vremenskog linearnog trenda $\hat{y}=b 0+b 1 x$, gde ŷ predstavlja linearnu funkciju, b0 (prosek) $i$ b1 (srednji apsolutni porast) predstavljaju ocene parametara, a $x$ predstavlja podatke vremena.(Mladenović i Nojković, 2015) Za izračunavanje ocene parametara trenda koristi se metod najmanjeg kvadrata.

\section{REZULTATI}

$\mathrm{U}$ istraživanju polazeći od podataka koje smo prikupili i metoda koje primenjujemo izvršili smo statističku pripremu podataka radi mogućnosti njihove obrade.

Tabela 1. Finansijski pokazatelji u Republici Srbiji u milionima dinara

\begin{tabular}{|c|c|c|c|c|c|c|}
\hline Godina & $\begin{array}{c}\text { Budžet } \\
\text { Republike } \\
\text { Srbije }\end{array}$ & $\begin{array}{c}\text { Izdvajanja iz } \\
\text { budžeta za } \\
\text { ZŽS }\end{array}$ & $\begin{array}{c}\text { Subvencije iz } \\
\text { budžeta RS } \\
\text { za zaštitu } \\
\text { životne } \\
\text { sredine }\end{array}$ & $\begin{array}{c}\text { Subvencije za } \\
\text { ponovnu } \\
\text { upotrebu i } \\
\text { ikorišćenje } \\
\text { otpada kao } \\
\text { sekundarne } \\
\text { sirovine }\end{array}$ & $\begin{array}{c}\text { Količina } \\
\text { prečišćene } \\
\text { otpadne vod } \\
\text { e }\end{array}$ & $\begin{array}{c}\text { Pokazatelji } \\
\text { industrijske } \\
\text { proizvodnje u } \\
\text { Srbiji }\end{array}$ \\
\hline 1 & 2 & 3 & 4 & 5 & 6 & 7 \\
\hline 2010 & $714.823,84$ & $1.571,34$ & 385,00 & 0 & $>6,3 \%$ & $2,50 \%$ \\
\hline 2011 & $804.947,31$ & $1.438,53$ & 361,00 & 0 & $>16,4 \%$ & $2,20 \%$ \\
\hline 2012 & $824.481,00$ & $1.321,52$ & 380,00 & 0 & $>7,3 \%$ & $-2,90 \%$ \\
\hline 2013 & $965.700,00$ & $7.771,98$ & 444,84 & 200,00 & $<3,7 \%$ & $5,50 \%$ \\
\hline 2014 & $929.902,00$ & $9.537,05$ & 630,00 & 300,00 & $>8,6 \%$ & $-5,50 \%$ \\
\hline
\end{tabular}

Izvor:http://www.nbs.rs/export/sites/default/internet/latinica/80/realni_sektor/SBRS01.xls,

http://www.mfin.gov.rs/pages/issue.php?sf=6\&id=1578

Izvršili smo analizu budžeta Republike Srbije (h) i izdvajanja iz budžet Republike Srije za zaštitu životne sredine $(\mathrm{u})$. Primenom PEARSON-OV metode korelacije ustanovili smo da vrednost korelacije iznosi ,rxy=0.86 što spada u jako pozitivnu korelaciju.

Ukoliko iz predhodne tabele kao pojavu (h) uzmemo izdvajanja iz budžeta Republike Srbije za projektovane godine (2010-2014), a kao pojavu (u) subvencije iz budžeta RS za zaštitu životne sredine, primenom PEARSON-OV metode korelacije ustanovili smo da je vrednost koeficijenta korelacije iznosi rxy $=0.88$ što spada u jako pozitivnu korelaciju.

Primenom PEARSON-OVE metode korelacije ustanovili smo da je vrednost koeficijenta korelacije, analizom (h) izdvajanja iz budžeta Republike Srbije za zaštitu životne sredine i (u) količine otpadnih voda iz industrije, rxy=0,38 što znači da je koeficijent korelacije u slabo pozitivnoj korelaciji.

Grafikon 1. Izdaci za finansiranje zaštite životne sredine

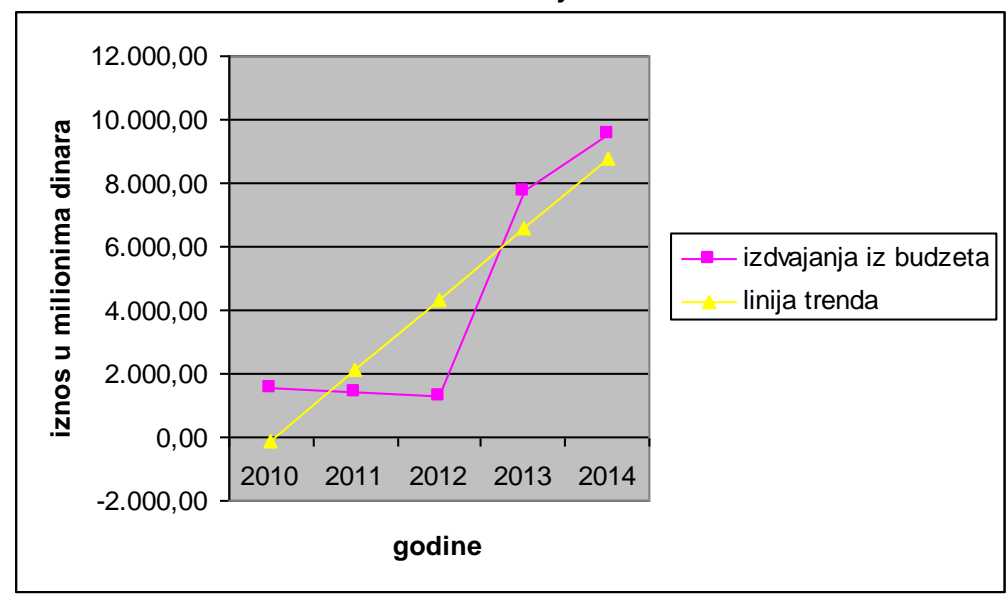


Izračunavanjem vremenskog linarnog trenda došli smo do modela linearnog trenda ŷ $=$ 4,328.08+2,226.49x, gde je prosek u posmatranom periodu kapitalnih rashoda 4,328.08 miliona dinara, a srednji apsolutni rast u predstavljenom periodu 2,226.49 miliona dinara. Izračunavanjem vrednosti trenda za 2020. godinu došli smo do rezultata od 22,139.99 miliona dinara.

\section{DISKUSIJA}

Analizirajući dobijene rezultate može se zaključiti da budžet Republike Srbije i izdvajanja iz budžeta Republike Srbije za zaštitu životne sredine, povezani u jako pozitivnoj korelaciji, što znači da u ovom slučaju rastom budžeta Republike Srbije, raste i izdvajanje iz budžeta za zaštitu životne sredine.

Povezanost ove dva predmeta upoređivanja, na prvi pogled, deluje pozitivno i optimistično za zaštitu životne sredine, jer izdvajanja Republike iz budžeta za zaštitu životne sredine prati i rast budžeta Republike. Ali dugoročno na finasiranje zaštite životne sredine se ne sme gledati kao na trošak države već kao na investiciju u budućnost. Ta investicija bi mogla da se ogleda u izgradnji projakata kao što su izgradnja parkova prirode, banja i sportskih terena. Ovakvim ulaganjem u finansiranje zaštitu životne sredine u velikoj meri bi moglo da rastereti državni budžet , a formiranjem fondova zaštite životne sredine finansiranje zaštite životne sredine bi bilo u velikoj meri nezavisno.

Još jedan važan nedostatak finansiranja zaštite životne sredine iz budžeta Republike Srbije je u tome što ona zavisi od ekonomske snage budžeta i ekonomske moći budžetskih korisnika. To znači da stanje i stepen zagađenosti životne sredine, koja utiče na zdravstveno stanje stanovništva, a kojoj je glavni izvor finasiranja budžet, zavisi isključivo od ekonomske snege jedne države. Formiranjem fondova za zaštitu životne sredine i pomenutim načinom finansiranja u vidu investicija u zaštitu životne sredine, imali bismo finansiranje zaštite životne sredine sa znatno manjim oslanjanjem na budžet Republike, koji bi bio u velikoj meri nezavisan od trenutnog ekonomskog stanja države.

Kao što je pomenuto najveći deo sredstava za zaštitu životne sredine dolazi iz budžeta Republike $\mathrm{s}$ toga je neophodno inspirisati zagađivače da preuzmu glavni teret finasiranja zaštite životne sredine. Zato je potrebna pojačana budnost i ozbiljniji rad državnih nadzornih institucija u vidu pojačanih inspekcija i kontrola poštovanja zakona o zaštiti životne sredine.

Još jedan važan faktor u zaštiti životne sredine je porast suvencija iz budžeta Republike Srbije a naročito subvencija za ponovnu upotrebu i korišćenje otpada kao sekundarne sirovine. Analiza nam govori da su i ova dva predmeta upoređivanja, izdvajanja iz budžeta Republike Srbije i subvencije iz budžeta Republike Srbije za zaštitu životne sredine, povezani u srednje pozitivnoj korelaciji, što znači da je porastom izdvajanja iz budžeta Republike Srbije rasle i subvencije iz budžeta. Savremeno uređene države u procesu zaštite životne sredine veliku pažnju daju na reciklaži sekundarnih sirovina i vraćanje u ponovnu upotrebu u istom ili drugom obliku. Zbog toga na otpad treba gledati kao na sekundarnu sirovinu iz koje se reciklažom proizvode određeni proizvodi neophodni duštvu. Reciklažom sekundarnih sirovina, pored osnovnog značaja zaštitita i očuvanje životne sredine, dobijamo znatno jeftiniju proizvodnju određenih proizvoda jer sirovina već postiji i nije potrebno izdvajanje za nabavku, a iz tabele se vidi jedna pozitivna i optimistična slika u vidu subvencionisanih ulaganja u ponovnu upotrebu i ikorišćenje otpada kao sekundarne sirovine.

Izdvajanja iz budžeta Republike Srbije za zaštitu životne sredine i količine otpadnih voda iz industirije, su u slabo pozitivnoj korelaciji, što znači da rastom izdvajanja iz budžeta Republike Srbije, količina otpadnih voda iz industrije neznatno opada. To nam govori da je rast industrijske proizvodnje u Srbiji stagnirao ili opadao. Na osnovu ovih pokazatelja za očekivati je da bi procenat prečišćene vode iz industrije rastao zbog manje količine otpadnih voda. Iz tabele se vidi da nije tako i da je procenat prečišćene vode iz industrije opadao.

Takođe, ako sagledamo činjenicu iz predhodne analize i pokazatelje iz tabele da procenat prečišćene vode iz industrije iz godine u godinu opada, možemo da zaključimo da je ulaganje industrije u smanjenju zagađenja i čistije tehnologije zaštite životne sredine nedovoljne. Primerom procenta prečišćene vode iz industrije, jasno se vidi koliko je neophodno ulaganje, pored izdvajanja iz budžeta Republike, ulaganje i glavnih zagađivača životne sredine a to je industrijska proizvodnja u zaštitu životne sredine.

Vremenskim linearnim trendom smo prikazali trend kretanja izdvajanja iz budžeta Republike Srbije, modelom linearnog trenda, kroz vremenski period od 2010. godine do 2014. godine. U dijagramu, izdvajanja iz budžeta Republike Srbije i model linearnog trenda, se vidi da je trend izdvajanja iz budžeta za zaštitu životne sredine rastao.

Primenom vremenskog linearnog trenda za predviđanje izdvajnja iz budžeta Republike Srbije za 2020. godinu, došli smo do rezutata da, ako bi se rast izdvajnja iz budžeta nastavio to bi predstaljalo veliki problem i opterećenje za budžet Republike Srbije. Veliki deo budžetskuh sredstava bi odlazio na 
zaštitu životne sredine što bi u velikoj meri moralo da se odrazi na neku drugu oblast finansiranja iz budžeta Republike Srbije.

\section{ZAKLJUČAK}

Potreba za zaštitu životne sredine predstavlja imperativ svake savremene države. Dinamika našeg društvenoekonomskog razvoja zahteva primenu savremnih tehničko-tehnoloških sistema koji će moći umanjiti zagađenje životne sredine. Za te potrebe neophodno je izdvojiti određene investicije, što predstavlja problem većine nerazvijenih zemalja. Pomenuli smo da finansiranje zaštite životne sredine predstavlja jedno od najvažnijih pitanja kada govorimo o zaštiti životne sredine, jer se finansira iz više izvora kao što su: finansiranja iz sektora privrede, prihoda od naknada i izvora međunarodnih donacija, u najvećoj meri iz budžeta Republke Srbije.

Statističkim metodama predstavili smo odnos između elemanata sistema zaštite životne sredine i njihovog finansijskog uporišta u ekonomskoj moći države. Najveći problem, potkrepljen validnim podacima, predstavlja to što se u najvećoj meri zaštita životne sredine finansira iz budžeta. Budžet Republike Srbije je rastao a uporedo sa tim rasla su i izdvajanja za zaštitu životne sredine i sve to je pozitivno kada je u pitanju finansiranje zaštite životne sredine. Potrebno je finansiranje u budućnost i nešto što će u budućnosti predstavljati izvor finansiranja u smislu investiranja u sportske centre, banje i parkove prirode itd.

Finansiranje u zaštitu životne sredine treba da bude konstantno i kvalitetno. Međutim ovakvo finansiranje nije moguće jer finansiranje zaštite životne sredine zavisi od ekonomske snage budžeta i ekonomske moći budžetskuh korisnika. Naše viđenje je da bi bilo neophodno ponovno formiranje fondova za zaštitu životne sredine, jer bi finansiranje bilo nezavisnije od stanja budžeta.

U očuvanje životne sredine potrebno je uključiti sve elemente društvenog sistema, a u prvi red treba svrstati najveće zagađivače kao što je industrijska proizvodnja. Takve zagađivače treba inspirisati da svojim ulaganje poprave i daju jednu ključnu notu u očuvanju i zaštiti životne sredine. Takvim odgovornim odnosom, ne samo da bi se očuvala životne sredina, već bi budžet Republike bio rasterećeniji.

I na kraju treba ponoviti da je finansiranje zaštite životne sredine jako važan činilac u zaštiti životne serdine. Da je velikim izdvajanjem uz budžeta država pokazala jedan nivo odgovornosti. Da je potrebno pronaći rešenje za konstantno i nezavisno finansiranje zaštite životne sredine. Da je potrebno inspirisati ključne zagađivače da svojim finanijskim delovanjem preuzmu deo finansiranja zaštite životne sredine i time smanje izdvajanja uz budžeta. Ni jedna od ovih elemenata kratke retrospektive ne može biti zadovoljena i realizovana ako se svest ljudi, kao i svih društvenih činilaca, o zaštiti životne sredine u potpunosti nepodčini prirodi, a ne priroda nama, boreći se da je ni u kom pogledu ne ugrozimo. Tako svesnim delovanjem ostavićemo iza sebe zdraviju prirodnu sredinu koja nam je itekako potrebna.

\section{LITERATURA}

1. Stiglic E. Dž, Ekonomija javnog sektora, prevod, Ekonomski fakultet, Beograd, 2008.

2. Radičić M, Raičević B, Javne finansije : teorija i praksa, Data status, Beograd, 2011.

3. Burda M., Viploš Č, Makroekonomija : evropski udžbenik, prevod 5. izd., Ekonomski fakultet, Centar za izdavačku delatnost, Beograd, 2012.

4. Žižić M,, Lovrić M, Pavličić D, Metodi statističke analize, Centar za izdavačku

5. delatnost Ekonomskog fakulteta, Beograd, 2007.

6. Mladenović Z, Nojković A, Primenjena analiza vremenskih serija, Centar za izdavačku delatnost Ekonomskog fakulteta, Beograd, 2015.

7. Novitović $O$, Randjić $D$, Novitović A, Zaštita životne sredine, Uzice, 2009.

8. http://www.nbs.rs/export/sites/default/internet/latinica/80/realni_sektor/SBRS01.xls

9. http://www.mfin.gov.rs/pages/issue.php?sf=6\&id=1578

\section{Abstract}

Financing environmental protection is one of the main goals of any modern state. Focusing on the financial institution like the budget we present level of needs and possibilities of meeting the basic needs regarding the establishment and functioning environmental protection system.

Using statistical methods present the causal relationships between the elements of environmental protection systems and their financial bases in the economic power of the state in modern conditions the diameter of the Republic of Serbia.

Keywords: budget, environmental protection, co-financing.

Rad primljen: 02.10.2015.

Rad prihvaćen: 15.01.2016. 